\title{
The fibrinolytic enzyme system in hypertension
}

\author{
B. BENNETT, D. OGSTON, G. P. M. CRAWFORD, AND A.S. DOUGLAS
}

From the Department of Medicine, University of Aberdeen

SYNOPSIS Fibrinogen, fibrinogen-related antigen (FR-antigen), and components of the fib:inolytic enzyme system were measured in patients with essential hypertension, renal disease with and without hypertension, and normal subjects. Essential hypertension was associated with a decrease in plasminogen activator and an increase in FR-antigen. In renal disease these changes were accompanied by increases in plasminogen activation inhibitor, alpha $\mathbf{2}_{2}$-macroglobulin, alpha $\mathrm{a}_{\mathbf{1}}$-antitrypsin, and fibrinogen.

A reduction in fibrinolytic activity in association with increased levels of fibrinogen, plasminogen, and antiplasmin activity has been reported in patients with hypertension (Prokopowicz, Worowski, Poplawski, Gabryelewicz, and Niewiarowski, 1967). Persistence of fibrin deposited on blood vessel walls has been postulated as a factor in the development of malignant hypertension (Linton, Gavras, Gleadle, Hutchison, Lawson, Lever, Macadam, McNicol, and Robertson, 1969), and the deposition of fibrin in the glomerular capillaries may have particular relevance to the evolution of nephrosclerosis (Vassalli and McCluskey, 1965).

Accordingly we have studied patients with essential hypertension with respect to fibrinogen, FR-antigen (fibrin degradation products), and components of the fibrinolytic system and have compared the findings with those obtained in normal subjects and in patients with primary renal disease with and without hypertension.

\section{Methods}

COMPONENTS OF THE FIBRINOLYTIC SYSTEM

\section{Plasminogen activator}

This was measured by performing euglobulin clot lysis times, essentially by the method of Nilsson and Olow (1962). The results are expressed by plotting the times logarithmically against units of fibrinolytic activity (Sherry, Lindemeyer, Fletcher, and Alkjaersig, 1959), 10 units being arbitrarily equated with a lysis time of 50 minutes. Times of over 500 minutes were assigned a value of 1 unit for the purpose of calculation.

Received for publication 2 March 1973.

\section{Plasma plasminogen}

This was estimated by the caseinolytic technique of Alkjaersig, Fletcher, and Sherry (1959). One casein unit is equivalent to the release of $180 \mu \mathrm{g}$ of acidsoluble tyrosine-like material in 60 minutes.

\section{Serum inhibitor of plasminogen activation}

This was measured by the method of Bennett (1967). One unit of activation inhibitor was equivalent to the inhibition produced by $10^{-3}$ moles of epsilon-aminocaproic acid. This inhibitor develops during the coagulation process (Bennett, 1970).

\section{Alpha $_{1}$-antitrypsin and alpha $a_{2}$-macroglobulin}

These proteins, contributing the major part of plasma inhibition of plasmin, were assayed by a radial immunodiffusion technique (Mancini, Carbonara, and Heremans, 1965) using Behringwerke Partigen plates (Hoechst Pharmaceuticals).

\section{OTHER FACTORS}

\section{Plasma fibrinogen}

This was assayed by a modification (Ogston and Ogston, 1966) of the method of Ratnoff and Menzie (1951).

\section{Serum fibrinogen-related antigen}

This was measured by the method of Merskey, Kleiner, and Johnson (1966).

\section{Patients}

Hypertension was defined as a persistent elevation of the diastolic blood pressure above $100 \mathrm{~mm} \mathrm{Hg}$. Diagnosis of the cause of the hypertension was made 
on the basis of clinical history, urine culture, plasma electrolytes, urinary protein and catecholamines, intravenous pyelography and, where appropriate, renal biopsy, renogram, and aortogram. Seventeen patients had essential hypertension with a urea level under $50 \mathrm{mg} / 100 \mathrm{ml}$ : their ages ranged from 27 to 67 years (mean 50.5). Twenty-six patients aged 14 to 61 years (mean 39.1) with renal parenchymatous disease were studied. Two had pyelonephritis and 24 had glomerulonephritis; of these eight showed a nephrotic phase during the course of the disease. Blood urea levels ranged from 15 to $410 \mathrm{mg} / 100 \mathrm{ml}$. None was on dialysis. These patients were divided into hypertensive (14) and normotensive (12) groups.

Control values were obtained from healthy subjects or from patients convalescent from minor disorders; their ages ranged from 35 to 66 years (mean 50-2).

\section{Results}

Patients with essential hypertension had a small decrease in the mean plasminogen activator level (table I). In addition, the mean FR-antigen level was significantly raised in these patients, but none had a level exceeding $27 \mu \mathrm{g} / \mathrm{ml}$. There was no relationship between the level of either factor and the degree of hypertension. The level of all other factors measured did not differ significantly from normal subjects.

In contrast to the patients with essential hypertension, patients with renal parenchymal disease and hypertension showed elevated levels of fibrinogen, serum inhibitor of plasminogen activation, serum

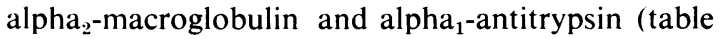
1) ${ }^{1}$. Patients suffering from renal parenchymal disease who were normotensive showed alterations of the fibrinolytic system components which did not differ substantially from that seen in the hypertensive subjects with renal disease. Fibrinogen and alpha $a_{2}-\vec{\Rightarrow}$ macroglobulin levels are age-dependent: the differences in the levels in patients with renal disease from the other groups, however, are greater than 흘 would be expected from the influence of age. In both $\frac{\bar{\sigma}}{\sigma}$ hypertensive and normotensive patients with renal $\stackrel{\varnothing}{\varrho}$ disease this pattern of changes was seen in individuals $\cong$ both with and without a rise in the blood urea levels.

\section{Discussion}

In agreement with Prokopowicz and his colleagues옹 (1967) we have found that fibrinolytic activity, as $\underset{\sim}{\mathrm{N}}$ measured by the euglobulin lysis time, is reduced in of patients with uncomplicated essential hypertension. In contrast to their observations, however, no alteration in other components of the fibrinolytic $\frac{\text { 의 }}{2}$ system or fibrinogen was evident. We have addi- $\rightarrow$ tionally observed a small elevation of the mean level of FR-antigen in these patients.

In marked contrast to the patients with essential $\vec{\theta}$ hypertension, the individuals with hypertension $\omega$ secondary to renal parenchymatous disease had 0 marked increases in levels of inhibitors of plasminogen activation, serum alpha ${ }_{2}$-macroglobulin, alpha $a_{1}-$ antitrypsin, plasma fibrinogen, and a higher mean level of FR-antigen. A number of these changes have been observed previously in patients with renal disease (McNicol, Barakat, and Douglas, 1965; Stiehm and Trygstadt, 1969; Wardle, Menon, and

\footnotetext{
Only in the case of plasminogen activator and inhibitor of plasminogen activation were the results from normotensive renal disease patients subjected to statistical analysis, as the mean values of the other parameters measured represented only small numbers of observations. However, it is evident from table $I$ that a trend in mean values of each 3 parameter was similar in the hypertensive and normotensive patients with renal disease.
}

\begin{tabular}{|c|c|c|c|c|}
\hline & \multirow[t]{2}{*}{ Normal Subjects } & \multirow[t]{2}{*}{ Essential Hypertension } & \multicolumn{2}{|c|}{ Renal Parenchymatous Disease } \\
\hline & & & Hypertensive & Normotensive \\
\hline Activator (units) & $\frac{4 \cdot 2}{(50)}=1 \cdot 5$ & $\frac{3 \cdot 3}{(17)} \pm 1 \cdot 5^{1}$ & $\underset{(12)}{3 \cdot 2}=1 \cdot 6^{1}$ & $\begin{array}{l}3.7 \quad \therefore 1.9 \\
(9)\end{array}$ \\
\hline Plasminogen (units/ml) & $\begin{array}{l}4 \cdot 4=0.5 \\
(110)\end{array}$ & $\begin{array}{l}4.5 \\
(17)\end{array}$ & $\begin{array}{l}4.4: 0.9 \\
(10)\end{array}$ & $\begin{array}{l}4 \cdot 3 \\
(3)\end{array}$ \\
\hline Activation inhibitor (units) & $\frac{3 \cdot 4}{(22)}=1.0$ & $\begin{array}{c}3 \cdot 3 \\
(17)\end{array}$ & $\begin{array}{l}8 \cdot 0 \\
(14)\end{array}-2 \cdot 1^{4}$ & $\begin{array}{l}9 \cdot 5 \div 1 \cdot 1^{4} \\
(12)\end{array}$ \\
\hline Alpha ${ }_{1}$-antitrypsin $(\mathrm{mg} / 100 \mathrm{ml})$ & $\begin{array}{l}275 \\
(80)\end{array}$ & $\begin{array}{l}274=54 \\
(15)\end{array}$ & $\begin{array}{l}322 \div 74^{1} \\
(9)\end{array}$ & $\begin{array}{l}241 \\
(3)\end{array}$ \\
\hline Alpha $\mathrm{a}_{2}$-macroglobulin $(\mathrm{mg} / 100 \mathrm{ml})$ & $\begin{array}{l}276 \div 47 \\
(80)\end{array}$ & $\begin{array}{l}286: 61 \\
(15)\end{array}$ & $\begin{array}{l}409 \div 112^{4} \\
(9)\end{array}$ & $\begin{array}{l}450 \\
(3)\end{array}$ \\
\hline Fibrinogen $(\mathrm{mg} / 100 \mathrm{ml})$ & $\begin{array}{l}357: 50 \\
(110)\end{array}$ & $\begin{array}{l}384 \div 80 \\
(17)\end{array}$ & $\begin{array}{l}564 \div 171^{4} \\
(10)\end{array}$ & $\begin{array}{l}463 \\
(3)\end{array}$ \\
\hline FR-antigen $(\mu \mathrm{g} / \mathrm{ml})$ & $\begin{array}{l}5 \cdot 6=4 \cdot 1 \\
(30)\end{array}$ & $\begin{array}{l}10 \cdot 7=7 \cdot 9^{3} \\
(17)\end{array}$ & $\begin{array}{l}15 \cdot 0 \pm 14 \cdot 4^{3} \\
(10)\end{array}$ & $\begin{array}{l}8 \cdot 8 \\
(2)\end{array}$ \\
\hline
\end{tabular}

Table Findings (means $\div S D$ ) in control subjects and in patients with essential hypertension and renal parenchymatous disease

Number of subjects in parentheses

Significance of difference from normal subjects ${ }^{1} \mathrm{P}<0.05,{ }^{2}<0.01,{ }^{3}<0.005,{ }^{4}<0.001$ 
Rastogi, 1970; Bennett and Ogston, 1970), but their relationship to the development of hypertension was not considered in these studies.

The relationship of changes in the fibrinolytic enzyme system to the development of hypertension is not clear. The alteration observed in patients with essential hypertension was minor: those observed in patients with renal disease were marked, but were present both in the presence and absence of hypertension. If, therefore, the changes in the fibrinolytic system contribute to the development of hypertension, either by a direct effect on arterial walls or indirectly by securing perpetuation of renal damage, the existence of an additional factor not measured in this study must be postulated. The time for which the abnormalities had been present might represent such a factor as might the presence of an agent initiating fibrin deposition. Alternatively, it is possible that the alterations in the fibrinolytic system are simply consequences of the renal damage and may not be closely related to the development of hypertensive disease since only a minor abnormality in the fibrinolytic system was evident in patients whose hypertension was not secondary to renal disease.

The presence of FR-antigen in serum is often regarded solely as evidence of enhanced fibrinolytic activity. In the absence of any significant increase in plasma fibrinolytic activity or decrease in plasminogen the significance of elevated levels of these antigens must be interpreted with care. If they reflect activity of the fibrinolytic system it must be assumed that this occurs locally in the vascular tree, presumably secondary to fibrin deposition, without causing alteration of the fibrinolytic components of circulating blood. Alternatively, the presence of the antigen may be due to circulation of fibrin in soluble form, perhaps complexed with other proteins, independent of any fibrinolytic process (Shainoff and Page, 1962). In both cases the presence of FRantigen in the blood reflects a coagulation process. The elevation of FR-antigen level observed in both essential hypertension and that secondary to renal disease was small. The importance of low-grade intravascular coagulation, even over a prolonged period, remains speculative but the changes noted are consistent with such a process occurring in both forms of hypertension.

The findings of this study indicate that hypertension may develop in the absence of severely disordered fibrinolytic activity. In renal disease reduced fibrinolytic activity is the rule whether hypertension has developed or not. In both forms of hypertension a small but significant elevation in levels of circulating FR-antigen occurs. Fibrin persistence due to reduced fibrinolytic activity seems unlikely to play a role in the development of essential hypertension, but may, possibly, in combination with other factors, contribute directly or indirectly to the progression of the hypertension of renal parenchymatous disease.

We thank Mrs Helen Lee and Mrs Naomi Hoogstadt for technical assistance, and our clinical colleagues for permission to study their patients.

\section{References}

Alkjaersig, N., Fletcher, A. P., and Sherry, S. (1959). The mechanism of clot dissolution by plasmin. J. clin. Invest., 38, 1086-1095.

Bennett, N. B. (1967). A method for the quantitative assay of inhibitor of plasminogen activation in human serum. Thrombos. Diathes. haemorrh. (Stuttg.), 17, 12-22.

Bennett, N. B. (1970). Further studies on an inhibitor of plasminogen activation in human serum. Release of the inhibitor during coagulation and thrombus formation. Thrombos. Diathes. haemorrh. (Stuttg.), 23, 553-561.

Bennett, N. B., and Ogston, D. (1970). Inhibitors of the fibrinolytic enzyme system in renal disease. Clin. Sci., 39, 549-557.

Linton, A. L., Gavras, H., Gleadle, R. I., Hutchison, H. E., Lawson, D. H., Lever, A. F., Macadam, R. F., McNicol, G. P., and Robertson, J. I. S. (1969). Microangiopathic haemolytic anaemia and the pathogenesis of malignant hypertension. Lancet, 1, 1277-1282.

McNicol, G. P., Barakat, A. A., and Douglas, A. S. (1965). Plasma fibrinolytic activity in renal disease. Scot. med. J., 10, 189-194.

Mancini, G., Carbonara, A. O., and Heremans, J. F. (1965). Immunochemical quantitation of antigens by single radial immunodiffusion. Immunochemistry, 2, 235-254.

Merskey, C., Kleiner, G. J., and Johnson, A. J. (1966). Quantitative estimation of split products of fibrinogen in human serum, relation to diagnosis and treatment. Blood, 28, 1-18.

Nilsson, 1. M., and Olow, B. (1962). Fibrinolysis induced by streptokinase in man. Acta chir. scand., 123, 247-266.

Ogston, C. M., and Ogston, D. (1966). Plasma fibrinogen and plasminogen levels in health and in ischaemic heart disease. $J$. clin. Path., 19, 352-356.

Prokopowicz, J., Worowski, K., Popławski, A., Gabryelewicz, A., and Niewiarowski, S. (1967). Fibrinolytic system in patients with hypertensive, cardiovascular disease. Thrombos. Diathes. haemorrh. (Stuttg.),17, 1-7.

Ratnoff, O. D., and Menzie, C. (1951). A new method for the determination of fibrinogen in small samples of plasma. J. Lab. clin. Med., 37, 316-320.

Shainoff, J. R., and Page, I. H. (1962). Significance of cryoprofibrin in fibrinogen-fibrin conversion. J. exp. Med., 116, 687-707.

Sherry, S., Lindemeyer, R. I., Fletcher, A. P., and Alkjaersig, N. (1959). Studies on enhanced fibrinolytic activity in man. J. clin. Invest., 38, 810-822.

Stiehm, C. R., and Trygstadt, C. W. (1969). Split products of fibrin in human renal disease. Amer. J. Med., 46, 774-786.

Vassalli, P., and McCluskey, R. T. (1965). The coagulation process and glomerular disease. Amer. J. Med., 39, 179-183.

Wardle, E. N., Menon, I. S., and Rastogi, S. P. (1970). Study of proteins and fibrinolysis in patients with glomerulonephritis. Brit. med. J., 2, 260-263. 